\title{
Intraspecific genetic variation in Corynandra chelidonii (Angiosperms: Cleomaceae) as revealed by SCoT, ISSR and RAPD analyses
}

\author{
Subash Sirangi - Phanikanth Jogam - Gandhi Nemali - Ragan Ajmeera - Sadanandam Abbagani - Vatsavaya S. Raju
}

Received: 7 July 2020 / Revised: 23 August 2020 / Accepted: 24 August 2020

(C) Korean Society for Plant Biotechnology

\begin{abstract}
The genetic diversity of two subpopulations of Corynandra chelidonii, one of terrestrial and the other of aquatic environments, was measured with molecular markers, such as start codon targeted (SCoT), inter simple sequence repeats (ISSR), and random amplification of polymorphic DNA (RAPD). The traditional morphological traits such as habitat, habit, leaf morphology, the colour of the sepals and petals, number of stamens, and seed morphology formed the base for their realization as two varieties, $C$. chelidonii var. pallae and C. chelidonii var. chelidonii. The polymorphism between the two variants was $100 \%$ with the primers SCoT-2 and OPA-1 and 4, while maximum polymorphism was detected with ISSR-2, SCoT-3, and OPA-3. The study used, for the first time, more than one molecular marker to assess the genetic variation underscoring the morphological variation in Corynandra chelidonii (L.f.) Cochrane \& Iltis. The study justifies the recognition of the two subpopulations of Corynandra chelidonii from aquatic and terrestrial environments as two distinct varieties, $C$. chelidonii var. pallae (Reddy \& Raju) V.S.Raju and C. chelidonii var. chelidonii, respectively, based on the traditional taxonomic evidence.
\end{abstract}

Keywords Cleome chelidonii, varieties, genetic variation analyses, molecular markers, taxonomic status assessment

\section{Introduction}

Cleomaceae Bercht. \& J. Presl is a now a well-recognized

${ }^{\dagger}$ Subash Sirangi and Phanikanth Jogam equally contributed to this work.

S. Subash · G. Nemali · A. Ragan · Vatsavaya S. Raju $(\bowtie)$ Department of Botany, Kakatiya University, Warangal, Telangana - 506009, India

e-mail: rajuvatsavaya@gmail.com

P. Jogam $\cdot$ A. Sadanandam

Department of Biotechnology, Kakatiya University, Warangal, Telangana - 506009, India family under Brassicales, placed in between Capparaceae and Brassicaceae (APG IV 2016). Corynandra Schard. ex Spreng is a segregate genus of Cleome (Cleomaceae), which was reinstated recently (Cochrane and Iltis 2014). The commonly available species of Cleome in India, such as Cleome chelidonii L.f., C. feline L.f., C. flava Banks ex DC., and C. viscosa $\mathrm{L}$. belong to Corynandra and, therefore, were transferred to it.

Cleome chelidonii var. pallae C.S.Reddy \& V.S.Raju is a new variety described from the littoral waters of Pakhal reservoir in Pakhal Reserve Forest, Mahabubabad district, Telangana state, India (Reddy and Raju 2001). It is a taxon growing in the fringes of lentic and/or lotic water bodies as tall plants with $3 \sim 6$ foliolate proximal and linear distal leaves, pink flowers, more number of stamens, and somewhat different seeds. While transferring Cleome chelidonii to Corynandra, Cohrane and Iltis (2014) have not transferred this variety but merely listed it as a synonym, mentioning that they have not seen the type material. Recently, Subash and Ragan (2017) studied the seed dormancy and in vitro germination of the seeds in Corynandra chelidonii var. pallae (Reddy \& Raju) V.S.Raju. Somkumar et al. (2018) reported this variety as a new record from Nagpur for Maharashtra state, India. Conversely, there is a need to assess whether there is any other evidence that corroborates its distinctiveness as an intraspecific taxon or not?

The seeds of Cleome chelidonii are used as a condiment by the local people. It contains medicinal compounds like glucocapparin and glucocleomin and the suspension cultures of it produced glucosinolates (Songsak and Lockwood 2002). Parimalakrishnan et al. (2007) studied the anti-inflammatory, antinociceptive and antipyretic effects of methanol extract of Cleome chelidonii. Anti-inflammatory and hepatoprotective activities of different extracts of Cleome chelidonii root was evaluated in albino rats (Ethadi et al. 2013). Sridhar et al. (2014) screened in vitro the methanolic extracts of Cleome chelidonii and C. gynandra for antimicrobial activity. Re- 
cently, Sumitha and Gurulakshmi (2015) studied antioxidant and free radical scavenging activity of leaf extracts of $C$. chelidonii while Minh et al. (2015) isolated two new flavonol glycosides from the leaves of $C$. chelidonii.

The spatial distribution of genetic variation within plant populations is influenced by many factors such as gene flow, micro-environmental selection, spatial distribution pattern, life history, and human activities (Ying et al. 2007). The study of genetic diversity with molecular markers among the plant species has become crucial for understanding the genetic variation (Frascaroli et al. 2013). Screening of genetic variations among different species is essential in conservation genetics and molecular breeding techniques (Kalia et al. 2011; Shekhawat et al. 2018). Different molecular markers like Start Codan Targeted (SCoT), Inter-Simple Sequence Repeat (ISSR), Restriction Fragment Length Polymorphism (RFLP), Simple Sequence Repeats (SSR), Amplified Fragment Length Polymorphism (AFLP), and Random Amplified Polymorphic DNA (RAPD) are important tools for evaluating genetic variation among various genotypes (Frascaroli et al. 2013; Kudikala et al. 2020; Shekhawat et al. 2018). K'Opondo et al. (2009) assessed the genetic variation in the morphotypes of Cleome gynandra in Kenya. So, an attempt was made here to evaluate the extent of genetic difference between the subpopulations of Cleome chelidonii in Telangana state, India, using the molecular markers such as SCoT, ISSR, and RAPD. It was to assess their bearing on the taxonomy of the species.

\section{Materials and Methods}

The plant material

The plant material of Corynandra chelidonii var. chelidonii and $C$. chelidonii var. pallae were collected from the districts of Warangal Rural and Mahabubabad (Pakhal RF, Pakhal tank), northern Telangana, India $\left(17.9526^{\circ} \mathrm{N} ; 80.0060^{\circ} \mathrm{E}\right)$. The taxa were identified and authenticated by Professor Dr. Vatsavaya S. Raju, Plant Systematics Laboratory, Kakatiya University, Warangal. The voucher specimens were deposited in KUW (Kakatiya University Herbarium, Warangal, India).

\section{DNA isolation}

The total DNA was isolated from the plants of the two varieties of Corynandra chelidonii (Taxon A: 'var. pallae' and Taxon B: 'var. chelidonii') using modified Cetyl trimethyl ammonium bromide (CTAB) method (Doyle and Doyle 1987). The quality of DNA was checked on $0.8 \%$ agarose gel with $1 \mathrm{X}$ TAE buffer adjusted to $50 \mathrm{ng} / \mu \mathrm{l}$ with TE buffer and stored at $-20^{\circ} \mathrm{C}$.

Analysis of genetic variation using SCoT, ISSR, and RAPD markers

Three sets of markers were used for genetic variation studies of Corynandra chelidonii. The PCR analysis was performed with 4 primers, each of SCOT, ISSR, and RAPD (Table 1). The PCR amplification was performed using a

Table 1 List of SCoT, ISSR, and RAPD markers used in genetic study

\begin{tabular}{cclcccc}
\hline S. No. & Primer Code & Primer Sequence (5-3) & $\begin{array}{c}\text { Total number } \\
\text { of alleles }\end{array}$ & $\begin{array}{c}\text { Polymorphic } \\
\text { alleles }\end{array}$ & $\begin{array}{c}\text { Percentage } \\
\text { polymorphism }\end{array}$ & PIC \\
\hline 1 & SCoT-1 & CAACAATGGCTACCACCC & 6 & 2 & 33 & 0.193 \\
2 & SCoT-2 & CAACAATGGCTACCACCG & 1 & 1 & 100 & 0.032 \\
3 & SCoT-3 & ACGACATGGCGACCAACG & 7 & 5 & 71 & 0.225 \\
4 & SCoT-4 & CCATGGCTACCACCGCAG & 4 & 2 & 50 & 0.129 \\
5 & ISSR-1 & GAGAGAGAGAGAGAGAG & 12 & 8 & 66 & 0.387 \\
6 & ISSR-2 & GAGAGAGAGAGAGAGAT & 14 & 12 & 85 & 0.483 \\
7 & ISSR-3 & AGAGAGAGAGAGAGAGTC & 14 & 10 & 71 & 0.451 \\
8 & ISSR-4 & TGTGTGTGTGTGTGTGRA & 15 & 11 & 73 & 0.483 \\
9 & OPA-1 & CAGGCCCTTC & 1 & 1 & 100 & 0.032 \\
10 & OPA-2 & TGCCGAGCTG & 15 & 11 & 73 & 0.483 \\
11 & OPA-3 & AGTCAGCCAC & 12 & 8 & 66 & 0.387 \\
12 & OPA-4 & AATCGGGCTG & 1 & 1 & 100 & 0.032 \\
Total & & & 102 & 72 & & 0.296 \\
Average & & & 8.5 & 6 & 74 & 0 \\
\hline
\end{tabular}


total reaction volume of $50 \mu \mathrm{l}$ containing $50 \mathrm{ng} / \mu \mathrm{l}$ DNA, $10 \mathrm{p}$ mole of primer, and $2 \mathrm{X}$ PCR master mix (GCC Biotech, India) and amplification reaction was carried out in a thermal cycler (Eppendorf Germany) for 35 cycles with an initial denaturation of DNA at $94^{\circ} \mathrm{C}$ for $5 \mathrm{~min}$, followed by $30 \mathrm{sec}$ denaturation at $94^{\circ} \mathrm{C}$. The annealing done was $45 \mathrm{sec}$ each at $50^{\circ} \mathrm{C}$ for SCoT, ISSR, and $37^{\circ} \mathrm{C}$ for RAPD with $2 \mathrm{~min}$ extension at $72^{\circ} \mathrm{C}$, the final extension of $10 \mathrm{~min}$ at $72^{\circ} \mathrm{C}$, and cool down holding to $4^{\circ} \mathrm{C}$. All the PCR products were subjected to electrophoresis on $1 \%$ agarose gel using $1 \mathrm{X}$ TAE buffer. The size of amplicons was estimated using a 100 bp DNA ladder (Himedia), and the gels were photographed in a gel documentation system (Bio-Rad, USA). All amplification reactions were repeated thrice to check the reproducibility.

Each amplified product was scored either as 1 or 0 , corresponding to the presence or absence of a band. The frequency of microsatellite polymorphism was calculated based on the presence or absence of common bands. The polymorphism information content $(\mathrm{PIC})$ value $=\sum\left(1-\mathrm{Pi}^{2}\right) / \mathrm{n}$ where ' $\mathrm{n}$ ' is the number of band positions analyzed, and $P i$ is the frequency of the $i^{\text {th }}$ pattern band positions analyzed. The ability of the primers to distinguish the two variants was assessed by calculating their resolving power $(\mathrm{Rp})=$ $\sum I_{\mathrm{b}}$, where $I_{\mathrm{b}}$ is band informativeness, $I_{\mathrm{b}}=1-[2 \times(0.5-$ $p i)$ and $p i$ is the proportion of variants containing band $I$ (Prévost and Wilkinson 1999). The genetic associations among the two varieties were evaluated manually by counting the total number of bands/alleles (similar and dissimilar) using 4 primers each of SCoT, ISSR, and RAPD (Table 1). The PCR amplification was performed in triplicate, and the results obtained produced identical electrophoretic patterns. The molecular weight of all bands was calculated, and the binary matrix was prepared by scoring as a present (1) or absent (0). For each of the markers, PIC was calculated using Molecular Kinships version 3.0. The observed number of alleles $(\mathrm{Na})$, the effective number of alleles $(\mathrm{Ne})$, gene diversity $(\mathrm{H})$, Shannon's information index (I), relative differentiation (GST), the estimate of gene flow from [GST (Nm)], total heterozygosity $(\mathrm{Ht})$, within the subpopulation heterozygosity (Hs), genetic identity and genetic distance within population and group, number of polymorphic bands (NPB), and percentage of polymorphic bands (PPB) were calculated using Popgene version 1.32. The proportion of total genetic diversity residing among populations (GST) was calculated as GST $=(\mathrm{HT}-\mathrm{HS}) / \mathrm{HT}$, as described by Nei (1973), whereas the measures of genetic identity and genetic distance were after Nei and Roychoudhury (1972). The phenogram was constructed for the two variants based on UPGMA and modified NEIGHBOR producer of PHYLIP version 3.5.

\section{Results and Discussion}

Taxonomy of Cleome L.

The genus Cleome L. (1753), once placed in Capparaceae (Capparales), is now removed to Cleomaceae (Brassicales) of Rosids - Malvids - Eudicots of Angiosperms. Within the Cleomaceae, the genus Cleome L. was shown to be grossly paraphyletic (APG IV 2016). Several investigations were carried out about its naturalness in terms of macromolecules and biogeography (Barrett et al. 2017; Cochrane and Iltis 2014; Roalson et al. 2015; Zang and Tucker 2008). Of the several segregates of Cleome, Corynandra is the taxon to which the present investigation confines.

\section{Genus Corynandra}

The genus Corynandra Schard. ex Spreng. (1827) was reinstated as the earlier name for Arevila Raf. (1838), which was recently taken up as a distinct genus by Zhang and Tucker (2008). Cochrane and Iltis (2014), who reviewed this genus recently, justified its segregation from Cleome and transferred the taxa, which naturally belongs to it. Accordingly, the common weedy species like Cleome viscosa L. and Cleom chelidonii L.f. belong to Corynandra. The genus Corynandra is circumscribed by the closed aestivation of the flowers, the high number of stamens, adaxial filaments more or less apophysate, capsules sessile and erect with persistent valves that dehisce from the apex, and seed with an open cleft (Rao et al. 2018). The solitary flowers borne in the axils of upper leaves and an obsolete disk are the additional features associated with Corynandra against Cleome (Cochrane and Iltis 2014).

Corynandra chelidonii (L.f.) Cochrane \& Iltis in Novon 23: 22. 2014. Cleome chelidonii L.f. Suppl. Pl. 300. 1782. Polanisia chelidonii (L.f.) DC., Prodr. 1: 242. 1824. Aubion chelidonii (L.f.) Raf. Sylva Tellur. 110. 1838 (as “chelidoni”).

Distribution: India (throughout the country as a weed of fallow fields), Myanmar, and Malaysia.

The presence of two morphotypes of Cleome chelidonii, one on the land, and the other along the marginal of tanks in the district of Warangal, Andhra Pradesh (now Telangana 
Table 2 Morphological distinction between the two varieties of Corynandra chelidonii

\begin{tabular}{|c|c|c|}
\hline Character & var. chelidonii & var. pallae \\
\hline Habit & Annual erect herbs to $<1 \mathrm{~m}$ tall & Annual erect herbs to $1.5 \mathrm{~m}$ tall \\
\hline Habitat & Terrestrial; fallow fields, dried-up ponds & Aquatic to semi-aquatic \\
\hline $\begin{array}{l}\text { Leaflets: } \\
\text { (i) Basal (proximal) }\end{array}$ & $7 \sim 9$-foliolate, obovate, $3.5 \sim 12.2 \mathrm{~cm}$ long, entire & $\begin{array}{l}\text { Same as in typical form, but bigger; } 4-70.3 \sim \\
0.7 \mathrm{~cm} \text {; crenate to crenate-serrate }\end{array}$ \\
\hline (ii) Middle (mesial) & $5 \sim 7$-foliolate, elliptic to oblanceolate & $3 \sim 5$ foliolate, elliptic lanceolate \\
\hline (iii) Upper (distal) & $1 \sim 5$-foliolate, oblanceolate to lanceolate & $1 \sim 3$; foliolate; often linear \\
\hline $\begin{array}{l}\text { Internodes } \\
\text { Pedicel length }\end{array}$ & $\begin{array}{l}\text { Up to } 5 \mathrm{~cm} \\
4 \mathrm{~cm}\end{array}$ & $\begin{array}{l}\text { Up to } 15 \mathrm{~cm} \\
4.5 \mathrm{~cm}\end{array}$ \\
\hline Flowers & $1.5 \sim 2.0 \mathrm{~cm}$ across & $2.5 \sim 3.5 \mathrm{~cm}$ across \\
\hline Petals & $\begin{array}{l}\text { 4, close-by, elliptic, ovate to obovate; } 1 \sim 1.4 \times \\
0.3 \sim 0.8 \mathrm{~cm} \text {; pink }\end{array}$ & $\begin{array}{l}\text { 4, somewhat distant, oblong to ovate, } 1.5 \sim 1.8 \\
\mathrm{~cm} \text {; pink }\end{array}$ \\
\hline Stamens (no/filaments) & ca. $35 \sim 60 ; 0.8 \sim 1.2 \mathrm{~cm}$ long & ca. $60 \sim 100$ or more; $1.6 \sim 1.9 \mathrm{~cm}$ \\
\hline Capsule (beak length) & $2 \sim 4 \mathrm{~mm}$ & $5 \sim 10 \mathrm{~mm}$ \\
\hline Seeds & $\begin{array}{l}\text { Ovoidal, } 1.3 \sim 1.8 \mathrm{~mm} \text { across; cleft more closed; } \\
\text { testa tuberculate; appendages shorter, lesser, more } \\
\text { or less pointed; with no waxy coating. }\end{array}$ & $\begin{array}{l}\text { Rounded, } 1.5 \sim 2.5 \mathrm{~mm} \text { across; cleft more open; } \\
\text { testa tuberculate with blunt tubercles of different } \\
\text { heights; appendages with waxy coating. }\end{array}$ \\
\hline
\end{tabular}
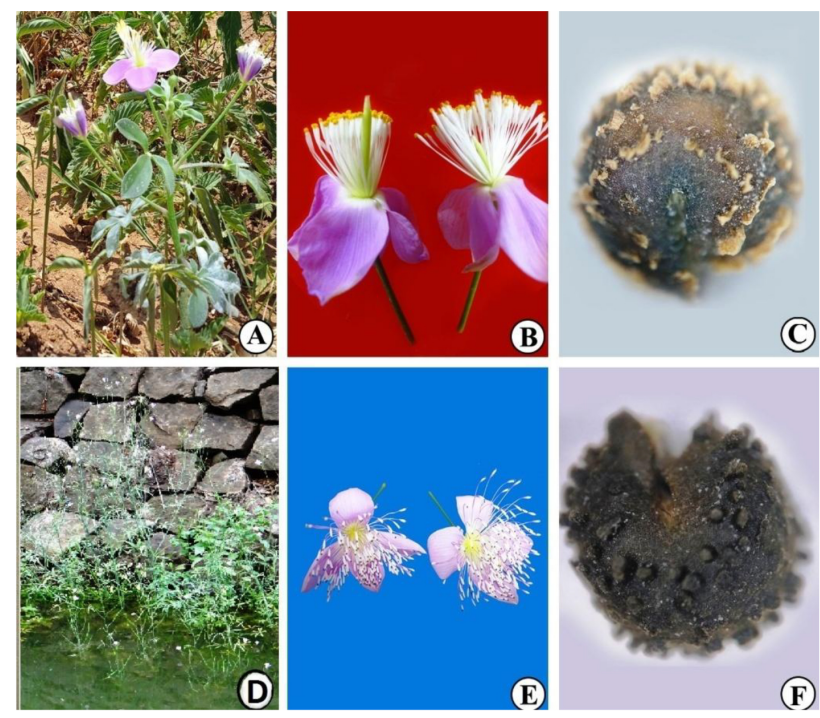

Fig. 1 The two varieties of Corynandra chelidonii. A-C: Habitat/habit, flowers, and seed image (Stereo binocular microscope Nikon SMZ 18 captured) of var. chelidonii; D-F: Habitat/habit, flowers, and seed of var. pallae

state) was noted by Vijayakumar (1980) in his light and SEM study of the seeds. Consequently, Reddy and Raju (2001) were the first to describe the aquatic form as a new variety, Cleome chelidonii var. pallai (Table 2; Fig.1). Technically speaking (Article 60.8(a) of the ICN), the varietal epithet 'pallai' has to be "var. pallae". The taxon was named after the late Dr. Palla Vijayakumar, Reader in Botany, Kakatiya University, Warangal, who worked on the seed morphology of Cleomaceae for his doctoral thesis.

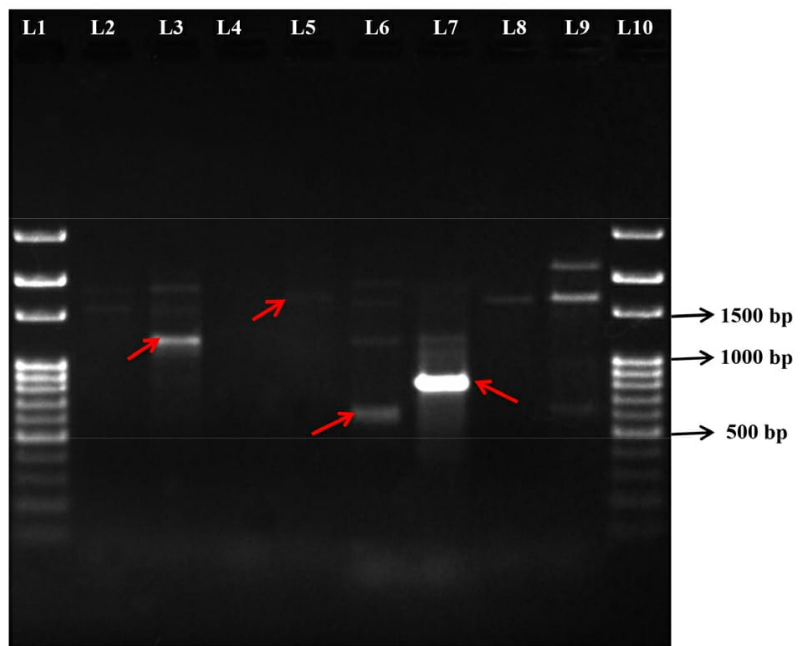

Fig. 2 Genetic variation in Corynandra chelidonii as disclosed by SCoT. Lane 1, Lane 10: 100 bp DNA ladder; Lane 2: var. pallae and Lane 3: var. chelidonii, with SCoT-1; Lane 4: var. pallae and Lane 5: var. chelidonii, with SCoT-2; Lane 6: var pallae and Lane 7: var. chelidonii, with SCoT-3; Lane 8: var. pallae and Lane 9: var. chelidonii, with SCoT-4 primer. SCoT: Start codon targeted

\section{Genetic diversity according to primers}

Three sets of markers (SCoT, ISSR, and RAPD) were used for genetic variation studies. The PCR analysis was performed with four primers each. Taxon-A (var. pallae DNA) with SCoT1 primer showed no band whereas Taxon-B (var. chelidonii) DNA showed the band in between 1000 and 1500 bp with SCoT1 (Fig. 2). Taxon-A DNA with SCoT3 


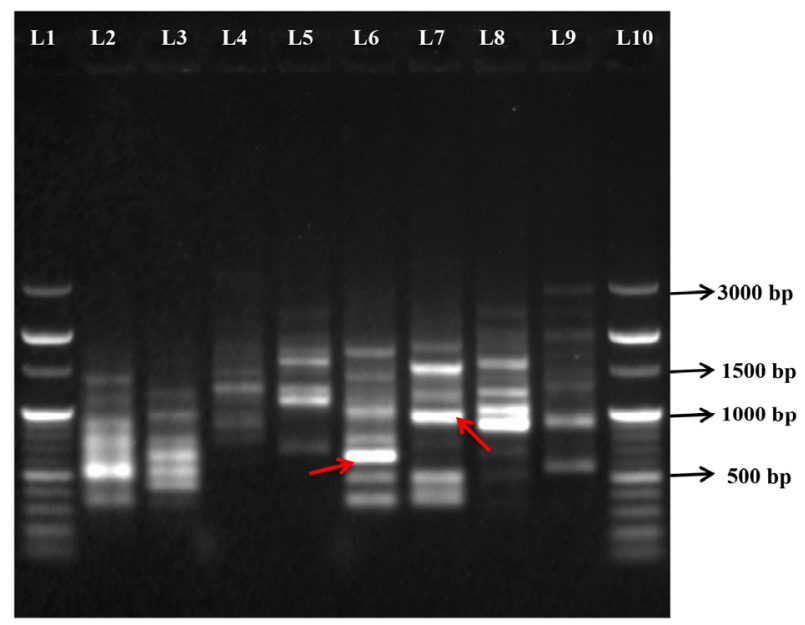

Fig. 3 Genetic variation in Corynandra chelidonii as per ISSR markers. Lane 1, Lane 10: 100bp DNA ladder; Lane 2: var. pallae and Lane 3: var. chelidonii, with ISSR-1; Lane 4: var. pallae and Lane 5: var. chelidonii, with ISSR-2; Lane 6: var. pallae and Lane 7: var. chelidonii, with ISSR-3; Lane 8: var. pallae and Lane 9: var. chelidonii, with ISSR-4 primer. ISSR: Inter simple sequence repeat

showed a band at $700 \mathrm{bp}$, whereas the Taxon-B DNA showed band around 1000 bp with SCoT3 (Fig. 2). In the case of ISSR analysis, ISSR3 primer showed band variation with the same primer: Taxon-A DNA showed a band at $600 \mathrm{bp}$ whereas Taxon-B DNA developed a band at 1000 bp (Fig. 3). In RAPD analysis, OPA-1 primer evinced no bands in Taxon-A, whereas the DNA of Taxon-B amplified showed a band at $1000 \mathrm{bp}$. The OPA-4 primer amplified evinced a band at $400 \mathrm{bp}$ in Taxon-A DNA whereas Taxon -B DNA produced no such band with the same primer (Fig. 4).

\section{Percentage of polymorphism}

The percentage of polymorphism was calculated according to the presence (1) or absence (0) of bands for SCoT, ISSR, and RAPD markers. The twelve primers used for genetic variation and diversity study generated 102 bands, an average 4.25 bands of SCoT, 14 bands of ISSR, and 7 bands of RAPD.

\section{Polymorphic Information Content (PIC)}

The genetic variation and differences were clearly seen between the two subpopulations of Corynandra chelidonii. The number of bands for Taxon-A in terms of markers was 9 (SCoT), 31 (ISSR), and 12 (RAPD). For Taxon-B, they were 8 (SCoT), 25 (ISSR), and 16 (RAPD). Among all primers, between two variants, the mean average PIC

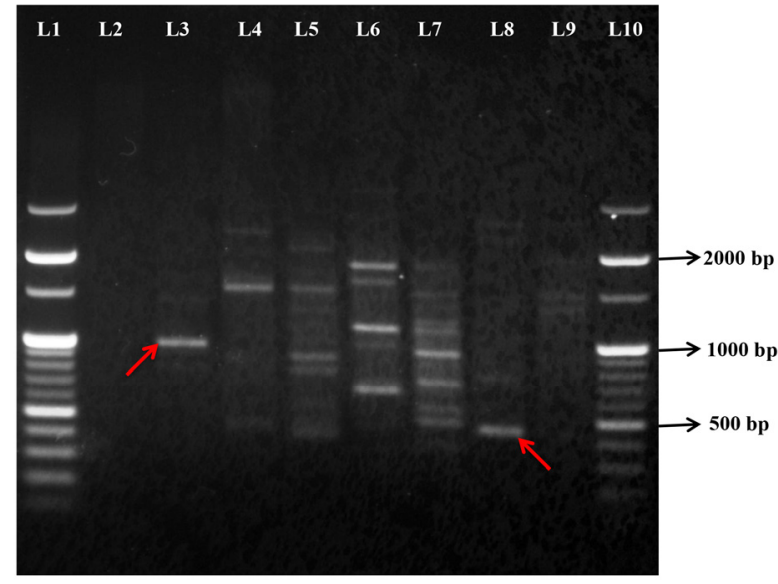

Fig. 4 Genetic variation in DNA of Corynandra chelidonii, as revealed by RAPD analysis. Lane 1, Lane 10: 100bp DNA ladder. Lane 2: var. pallae and Lane 3: var. chelidonii, with OPA-1; Lane 4: var. pallae and Lane 5: var. chelidonii, with OPA-2; Lane 6: var. pallae and Lane 7: var. chelidonii with OPA-3; Lane 8: var. pallae DNA and Lane 9: var. chelidonii, with OPA-4 primer. RAPD: Random amplified polymorphic DNA

observed was 0.296. However, the highest mean (PIC 0.483) was shown with ISSR-2, ISSR-4, and OPA-2 (RAPD). On the other, the lowest mean (PIC 0.032) was observed with SCoT-2 and OPA-1 and OPA-4 (RAPD) (Table 1).

Genetic variation

The observed number of alleles (Na), effective number of alleles $(\mathrm{Ne})$, gene diversity $(\mathrm{H})$, Shannon's information index (I), total heterozygosity (Ht), within-population heterozygosity (Hs), number of polymorphic bands (NPB) and Percentage of polymorphic bands (PPB) were calculated for the estimation of genetic variation between the two (A and B) subpopulations (Table 3).

\section{Genetic variation between two taxa}

(i) The Primers SCoT exhibited the genetic variation of $\mathrm{Na}(1.225 \pm 0.425) \mathrm{Ne}(1.161 \pm 0.315), \mathrm{Np}(07$ (22.58)) $\mathrm{h}(0.092 \pm 0.176) \mathrm{I}(0.135 \pm 0.256)$ for Taxon- $\mathrm{A}$ and $\mathrm{Na}$ $(1.258 \pm 0.444), \mathrm{Ne}(1.167 \pm 0.297), \mathrm{Np}$ (08 (25.81)), h $(0.100 \pm 0.175)$, I $(0.149 \pm 0.258)$ for Taxon-B. (ii) The ISSR primers revealed the genetic variation as of $\mathrm{Na}$ $(1.548 \pm 0.50), \mathrm{Ne}(51.432 \pm 0.426), \mathrm{Np}(17$ (54.84)) h $(0.237 \pm 0.224)$ I $(0.342 \pm 0.319)$ in Taxon- $\mathrm{A}$ and $\mathrm{Na}$ $(1.580 \pm 0.501), \mathrm{Ne}(1.438 \pm 0.408), \mathrm{Np}$ (18 (58.06)), h ( $0.246 \pm 0.217)$, I $(0.356 \pm 0.311)$ for Taxon-B, and (iii) The RAPD primes have shown the genetic variation $\mathrm{Na}$ $(1.354 \pm 0.486), \mathrm{Ne}(1.238 \pm 0.340), \mathrm{Np}(11$ (35.48)), $\mathrm{h}$ 
Table 3 Genetic diversity and differentiation parameters for Taxon A and B subpopulations of Corynandra chelidonii

\begin{tabular}{|c|c|c|c|c|c|c|c|c|c|c|c|c|}
\hline \multirow{2}{*}{ Marker } & \multirow{2}{*}{ Population } & \multicolumn{11}{|c|}{ Diversity indices } \\
\hline & & na $( \pm \mathrm{SD})$ & ne $( \pm \mathrm{SD})$ & $\mathrm{Np}(\mathrm{Pl} \%)$ & $h( \pm \mathrm{SD})$ & $\mathrm{I}( \pm \mathrm{SD})$ & $\mathrm{Gd}$ & $\mathrm{Gi}$ & $\mathrm{Ht}$ & $\mathrm{Hs}$ & Gst & $\mathrm{Nm}$ \\
\hline \multirow[t]{2}{*}{ SCOT } & Taxon-A & $1.225 \pm 0.425$ & $1.161 \pm 0.315$ & $07(22.58)$ & $0.092 \pm 0.176$ & $0.135 \pm 0.256$ & 0.0135 & 0.986 & $0.102 \pm 0.026$ & $0.096 \pm 0.025$ & 0.058 & 8.000 \\
\hline & Taxon-B & $1.258 \pm 0.444$ & $1.167 \pm 0.297$ & $08(25.81)$ & $0.100 \pm 0.175$ & $0.149 \pm 0.258$ & & & & & & \\
\hline \multirow[t]{2}{*}{ ISSR } & Taxon-A & $1.548 \pm 0.505$ & $1.432 \pm 0.426$ & $17(54.84)$ & $0.237 \pm 0.224$ & $0.342 \pm 0.319$ & 0.0435 & 0.957 & $0.258 \pm 0.049$ & $0.241 \pm 0.044$ & 0.062 & 7.500 \\
\hline & Taxon-B & 1.5800 .501 & $1.438 \pm 0.408$ & $18(58.06)$ & $0.246 \pm 0.217$ & $0.356 \pm 0.311$ & & & & & & \\
\hline \multirow[t]{2}{*}{ RAPD } & Taxon-A & $1.354 \pm 0.486$ & $1.238 \pm 0.340$ & $11(35.48)$ & $0.141 \pm 0.195$ & $0.208 \pm 0.286$ & 0.0611 & 0.940 & $0.176 \pm 0.026$ & $0.151 \pm 0.020$ & 0.142 & 3.000 \\
\hline & Taxon-B & $1.387 \pm 0.495$ & $1.283 \pm 0.382$ & $12(38.71)$ & $0.161 \pm 0.209$ & $0.234 \pm 0.302$ & & & & & & \\
\hline \multirow[t]{2}{*}{$\begin{array}{c}\text { ALL } \\
\text { (primers) }\end{array}$} & Taxon-A & $1.612 \pm 0.495$ & $1.323 \pm 0.341$ & 19 (61.29) & $0.198 \pm 0.187$ & $0.303 \pm 0.271$ & 0.0133 & 0.986 & $0.208 \pm 0.028$ & $0.202 \pm 0.026$ & 0.025 & 19.255 \\
\hline & Taxon-B & $1.741 \pm 0.444$ & $1.314 \pm 0.278$ & $23(74.19)$ & $0.207 \pm 0.159$ & $0.328 \pm 0.231$ & & & & & & \\
\hline
\end{tabular}

\# value (mean) Taxon A: C. chelidonii var. pallae; Taxon B: C. chelidonii var. chelidonii.

$\mathrm{Gd}=$ Genetic distance; $\mathrm{Gi}=$ Genetic identity; $\mathrm{G}_{\mathrm{st}}=$ Degree of genetic differentiation; $\mathrm{h}=$ Nei's (1973) gene diversity; Hs = Average heterozygosity; $\mathrm{Ht}=$ Heterozygosity at the polymorphic loci; I = Shannon's Information index (Lewontin 1972); na = Observed number of alleles; ne = Expected number of alleles/Effective number of alleles (Kimura and Crow 1964); Nm = Estimate of gene flow from Gst or Gcs. e.g., $\mathrm{Nm}=0.5(1$ - Gst $) / \mathrm{Gst} ; \mathrm{Np}=$ Number of polymorphic; Pl = Percentage of polymorphic loci; see McDermott and McDonald 1993).
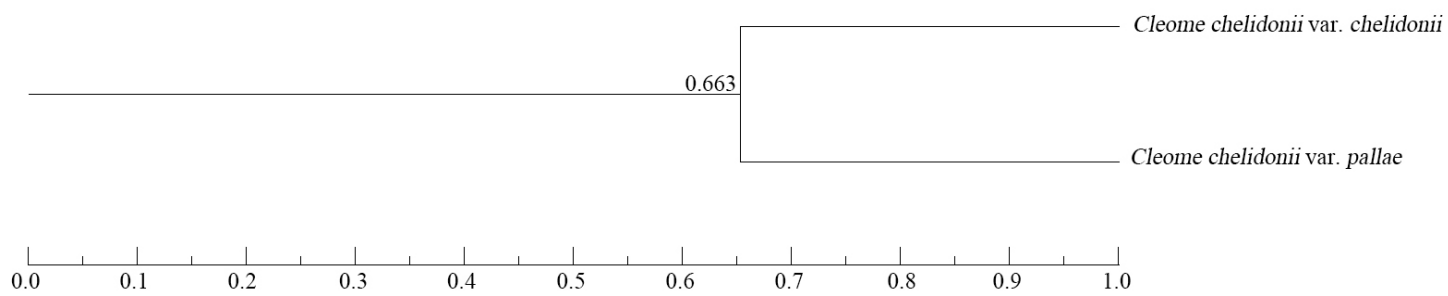

Fig. 5 Phenogram: Corynandra chelidonii varieties

$(0.141 \pm 0.195) \mathrm{I}(0.208 \pm 0.286)$ for Taxon- $\mathrm{A}$ in contrast to Taxon- $\mathrm{B}$ of $\mathrm{Na}(1.387 \pm 0.495), \mathrm{Ne}(1.283 \pm 0.382) \mathrm{Np}$ (12 (38.71) ) h $(0.161 \pm 0.209)$ I $(0.234 \pm 0.302)$ (Table 3$)$.

All the primers produced individual bands together for clear observation of genetic distance and variation between the two taxa as $\mathrm{Na}(1.612 \pm 0.495), \mathrm{Ne}(1.323 \pm 0.341)$, $\mathrm{Np}(19$ (61.29)), h $(0.198 \pm 0.187), \mathrm{I}(0.303 \pm 0.271)$ of Taxon-A and $\mathrm{Na}(1.741 \pm 0.444), \mathrm{Ne}(1.314 \pm 0.278), \mathrm{Np}$ (23 (74.19)), h $(0.207 \pm 0.159), \mathrm{h}(0.328 \pm 0.231)$ for Taxon-B, and together have shown a genetic distance $\mathrm{Gd}$ (0.0133), Gi (0.986), Ht (0.208 \pm 0.028$)$, Hs (0.202 \pm $0.026)$, Gst (0.025) and Nm (19.255). Nei's genetic similarity between the subpopulations (A-var. pallae and $\mathrm{B}^{-}$-var. chelidonii) was 0.9868 . The phenogram (Fig. 5) was constructed using UPGMA after cluster analysis based on random data using the cophenetic correlation coefficient (Rohlf and Fisher 1968; Rohlf 2000).

Relative differentiation and estimate of gene flow

Assessment of gene flow from one population to another is an essential parameter for the study of genetic diversity.
Gene flow is a collective term that includes all the mechanisms resulting in the movement of genes from one species to another. In this study, lower relative differences between these two taxa $0.025\left(\mathrm{G}_{\mathrm{st}}\right)$ indicates a high variation at a genetic level for these plants while the gene flow was showing high $\mathrm{Nm}$ value between them.

These results, as per SCoT, ISSR, and RAPD analyses, suggest that there is apparent variation within the species Corynandra chelidonii. The SCoT, RAPD, and ISSR markers were demonstrated to be not only effective techniques to screen genetic differences but also quick, very consistent, cost-effective and one can investigate the whole genome of the plant randomly (Jogam et al. 2020; Pendli et al. 2019; Rohela et al. 2020). The use of more than one molecular marker to detect the genetic dissimilarity is always useful for better results because every molecular marker has its benefits and drawbacks. Besides the genetic diversity studies, SCoT, ISSR, and RAPD molecular markers were also used in genetic fidelity analysis of micropropagated plants (Sadhu et al. 2020; Sirikonda et al. 2020; Thakur et al. 2016). There were similar assessments of genetic variation among various taxonomic groups and ranks of 
angiospermous taxa. For example, SCoT based genetic polymorphism studies were done in a wild population of Maytenus emarginata (Shekhawat et al. 2018). The SCoT markers were effectively applied for the genetic diversity determination of Echinacea varieties (Jedrzejczyk et al. 2020). The ISSR markers were used to study the molecular phylogeny and genetic diversity for the detection of interand intraspecies variation in Capparis (Tamboli et al. 2018). The ISSR primers were used to study the genetic variation in 56 Amaranthus accessions of three species (Stefunova et al. 2014). Sixty-two taxa of Vigna, with a focus on the species $V$. unguiculata, were studied to distinguish the taxa at the specific and infraspecific levels (Ajibade et al. 2000). Twenty-four SSR markers were utilized to evaluate the genetic variation across thirty-six guava varieties, including wild species (Kherwar et al. 2018). The ISSR markers were employed successfully to know the genetic polymorphism in two morphological variants of the exotic invasive Hyptis suaveolens in India (Gadidasu et al. 2011). Using RAPD and ISSR markers, the genetic variation was assessed among the populations of the medicinal herb Bacopa monnieri in central India (Tripathi et al. 2012).

\section{Taxonomic status}

The molecular data gathered in the present study of Corynandra chelidonii provides a genetic basis for the distinction of $C$. chelidonii var. pallae from the type. Since the phenetic similarity between the two taxa (subpopulations/varieties) compared is $66 \%$ (Fig. 5), the present authors inclined to accept them as varieties rather than subspecies. It is also because the subpopulations are not geographically isolated (allopatric), but ranged between adjacent terrestrial and aquatic environments. Corynandra elegans, which was recently described as a new species from the aquatic habitats in the Konkan region of Maharashtra, India (Chandore et al. 2016), was not realized as a species in the present study after comparison with its closely allied $C$. chelidonii var. pallae. In all probability, C. elegans does not stand as a distinct species but only proves to be this variety. The decision to merge it with C. chelidonii var. pallae is kept pending, awaiting the examination of the type material.

The presence of the aquatic form of Cleome chelidonii was reported in the past from India and elsewhere (Cooke 1996; Hewetson 1954; Raipur, now in Chhattisgarh; Jacobs 1960; Sundararaghavan 1993). But, Mirashi (1956) noted, in this form (which is now called C. chelidonii var. pallae), the mainly terrestrial race, showing hydrophytic nature and marked adaptation to watery habitat. Since the present study clearly establishes the genetic (molecular) and morphological (Table 2) variation between the two varieties of Corynandra chelidonii, there is a need to maintain them as distinct taxa. It is in contradiction to Cochrane and Iltis (2014) and Barrett et al. (2017) who merged them on the taxonomic grounds without examining those specimens in the field and herbaria. Therefore, we have in India and, perhaps elsewhere (e.g., Sri Lanka, Java), there exist two varieties under Corynandra chelidonii (L.f) Cochrane \& Iltis: one on terrestrial land (var. chelidonii) and another in freshwater marshes (var. pallae).

Corynandra chelidonii (L.f.) Cochrane \& Iltis var. pallae (C.S.Reddy \& V.S.Raju) V.S.Raju in Int. J. Res. Pharm. Biol. Sci. 7(2): 240. (April-June) 2017. Corynandra chelidonii var. pallae (C.S.Reddy \& V.S.Raju) Kottaim. in Int. J. Curr. Res. Biosci. Pl. Biol. 6(10): 38. Oct. 2019 (isonym) Cleome chelidonii L.f. var. pallae C.S.Reddy \& V.S.Raju in J. Econ. Tax. Bot. 25(1): 217.2001 ("pallai"). Type: INDIA, Telangana state, Mahabubabad distr., Pakhal Lake margins: 8.08.1961, K.M. Sebastine 13106 (MH).

Distribution: India (Maharashtra, Madhya Pradesh, Chhattisgarh, Telangana, Andhra Pradesh and Tamil Nadu [Chengalput distr., Vadanthangal Waterbirds Sanctuary: 26.09.1974, A.N. Henry 45447 at MH: V.S. Raju, per. obs.], Sri Lanka, Java, and Malaysia.

\section{Key to the varieties of Corynandra chelidonii}

1a. Plants terrestrial, of fallow fields; annual; erect herbs to $0.5 \mathrm{~m}$ height; leaflets elliptic to lanceolate; stamens about 60; distal leaves usually trifoliolate; seeds light brown, ovoidal, smaller (1.3 1.8 mm across); testa with tubercles pointed to curved, sparse; cleft somewhat closed ……............................ var. chelidonii

1b. Plants aquatic to semi-aquatic, of littoral zones of water bodies; largely annual; erect to clump-forming herbs to $1.5 \mathrm{~m}$ height; stamens $60 \sim 100$ or more; distal leaves linear; seeds dark brown, globose, bigger (1.5 $2.5 \mathrm{~mm}$ across); testa with tubercles straight and blunt, denser; cleft fairly open …….............. var. pallae

\section{Conclusion}

Of the three kinds of molecular markers used to screen the intraspecific genetic variation in Corynandra chelidonii, SCoT was found to be the best indicator in bringing out the genetic diversity. The genetic variation in the two plant subpopulation (terrestrial and aquatic) of Corynandra chelidonii 
was analyzed through several parameters like the number of alleles (Na), Number of polymorphic (Np), polymorphic loci percentage $(\mathrm{pl})$, gene diversity $(\mathrm{H})$ and Shannon's information index (I) revealed higher values for 'var. chelidonii' (Taxon-B) than 'var. pallae' (Taxon-A) in regard to $\mathrm{Na}, \mathrm{H}$, and I. Similarly, the observed and expected heterozygosity between var. chelidonii and var. pallae was high ( $\mathrm{Ht}[0.208$ $\pm 0.028]$; Hs $[0.202 \pm 0.026])$. So, for the infraspecific morphological and molecular diversity, there is obvious ground to realize two varieties in Corynandra chelidonii.

\section{Acknowledgments}

SS is grateful to the University Grants Commission, New Delhi, for the award of BSR-RFSMS Fellowship. The authors are thankful to the Heads of the Departments of Botany and Biotechnology, Kakatiya University, Warangal, for facilities. VSR is obliged to Dr. Kanchi N. Gandhi, Senior Nomenclatural Registrar, Harvard University, Herbaria and Libraries, USA, for the useful discussion on nomenclature and to Dr. C. Murugan, BSI_SRC, for permission to work in $\mathrm{MH}$.

\section{Conflict of interest}

The authors declare that they have no conflict of interest.

\section{References}

Ajibade SR, Weeden NF, Chite SM (2000) Inter simple sequence repeat analysis of genetic relationships in the genus Vigna. Euphytica 111(1):47-55; https://link.springer.com/article/ 10.1023/A: 1003763328768

APG (Angiosperm Phylogeny Group) IV (2016) An update of the Angiosperm Phylogeny Group classification for the orders and families of flowering plants: APG IV. Bot J Linn Soc 181:1-20

Barrett RL, Roalson EH, Ottewell K, Byrne M, Govindwar SP, Yadav SR, Tammboli AS, Gholave AR (2017) Resolving generic boundaries in Indian-Australasian Cleomaceae: Circumscription of Areocleome, Arivela, and Corynandra as distinct genera. Syst Bot 42:694-707; http://doi.org/10.1600/ $036364417 X 696401$

Chandore AN, Yadav US, Yadav SR (2016) A new elegant species of Corynandra (Cleomaceae) from Konkan region of Maharashtra, India. Phytotaxa 260(1):89-94; http://dx.doi. org/10.11646/ phytotaxa.260.1.10

Cochrane TS, Iltis HH (2014) Studies in the Cleomaceae VII: Five new combinations in Corynandra, an earlier name for Arivela.
Novon 23(1):21-26; http://doi.org/10.3417/ 2013023

Cooke CDK (1996) Aquatic and Wetland Plants of India. Oxford University Press, Cambridge

Doyle JJ, Doyle JL (1987) A rapid DNA isolation procedure for small quantities of fresh leaf tissue. Phytoch Bull 19:11-15

Ethadi SR, Pragada RR, Battu GR (2013) Evolution of antiinflammatory and hepatoprotective activities of different extracts of Cleome chelidonii root in albino rats. Int J Pharma Biosci 4:111-119

Frascaroli E, Schrag TA, Melchinger AE (2013) Genetic diversity analysis of elite European maize (Zea mays L.) inbred lines using AFLP, SSR, and SNP markers reveals ascertainment bias for a subset of SNPs. Theor App Gen 126(1):133-141

Gadidasu KK, Murthy EN, Nataraj P, Srinivas K, Babu PA, da Silva JAT, Raju VS, Sadanandam A (2011) ISSR markers reveal genetic polymorphism in two morphological variants of Hyptis suaveolens invasive to India. Med Aromat Plant Sci Biotechnol 5:166-168

Hewetson CE (1954) Systematics and ecology of Indian plants or what can be demand of a modern flora? J Bombay Nat Hist Soc 51(1\&2): 140-144

Jacobs M (1960) Capparidaceae. In: van Steens C.G.G.J. (ed) Flora Malesiana 6: 61-105. Wolters-Noordhoff Publishing, Goningen, Netherlands

Jedrzejczyk, I. (2020). Genome size and SCoT markers as tools for identification and genetic diversity assessment in Echinacea genus. Ind Crops Prod 144, 112055; https://doi.org/10.1016/ j.indcrop. 2019.112055

Jogam P, Sandhya D, Shekhawat MS, Alok A, Manokari M, Abbagani S, Allini VR (2020) Genetic stability analysis using DNA barcoding and molecular markers and foliar micromorphological analysis of in vitro regenerated and in vivo grown plants of Artemisia vulgaris L. Ind Crops Prod 151:112476; https://doi.org/10.1016/j.indcrop.2020.112476

K'Opondo FBO, van Rheenen HA, Muasya RM (2009) Assessment of genetic variation of selected spider plant (Cleome gynandra) morphotypes from western Kenya. African J Biotechnol 8(18):4325-4332

Kalia RK, Rai MK, Kalia S, Singh R, Dhawan AK (2011) Microsatellite markers: An overview of the recent progress in plants. Euphytica 177(3):309-334

Kherwar D, Usha K, Mithra SVA, Singh B (2018). Microsatellite (SSR) marker assisted assessment of population structure and genetic diversity for morpho-physiological traits in guava (Psidium guajava L.). J Plant Biochem Biotechnol 27(3): 284-292; https://link.springer.com/article/10.1007/s13562017-0438-2

Kimura M, F. Crow JF (1964) The number of alleles that can be maintained in a finite population. Genetics 49(4):725-738

Kudikala H, Jogam P, Sirikonda A, Mood K, Rao AV (2020) In vitro micropropagation and genetic fidelity studies using SCoT and ISSR primers in Annona reticulata L.: An important medicinal plant. Vegetos 33(3):446-457

Lewontin RC (1972) The apportionment of human diversity. Evol Biol 6:381-398 
McDermot JM, McDonald, BA (1993) Gene flow in plant pathosystems. Annu Rev Phytopathol 31:353-373

Minh PN, Tri MD, Phat NT, Dat BT, Hanh, NN, Luan NQ, Thanh MT, Huynh CH (2015) Two new flavonol glycosides from the leaves of Cleome chelidonii L.f. J Asian Nat Products Res 17(4):338-342

Mirashi MV (1956) Contribution to our knowledge of physiological anatomy of some Indian hydrophytes III. The stem of Cleome chelidonii Linn. Proc Indian Acad Sci 43B:233-236

Nei M (1973) The theory and estimation of genetic distance In: Morton NE (ed), Genetic Structure of Populations. pp. 45-51. University of Hawaii Press, Honolulu

Nei M, Roychoudhury AK (1972) Gene differences between Caucasian, Negro, and Japanese populations. Sci 177: 434-436

Parimalakrishnan S, Dey A, Smith AA, Manavalan R (2007) Evaluation of antiinflammatory, antinociceptive and antipyretic effects of methanol extract of Cleome chelidonii. Int J Biol Chem Sci 1(3):223-228

Pendli S, Rohela GK, Jogam P, Bylla P, Korra R, Thammidala C (2019) High frequency in vitro plantlet regeneration in Solanum trilobatum L., an important ethno-medicinal plant and confirmation of genetic fidelity of R1 plantlets by using ISSR and RAPD markers. Vegetos 32(4):508-520; https://doi.org/ 10.1007/s42535-019-00069-6

Prévost A, Wilkinson MJ (1999) A new system of comparing PCR primers applied to ISSR fingerprinting of potato cultivars. Theret App Gen 98(1):107-112; https://doi.org/10.1007/ s001220051046

Rao VH, Rao VV, Reddy AB, Raju VS (2018) The status assessment of Corynandra viscosa subsp. nagarjunakondensis (Magnoliopsida: Cleomaceae), endemic to Nagarjunakonda, Andhra Pradesh, India. J Threat Taxa 10(9); https://doi.org/ 10.11609/jott.3798. 10.9.12210-12217

Reddy CS, Raju VS (2001) A new variety of Cleome chelidonii L.f. (Cleomaceae). J Econ Taxon Bot 25(1):217, 218

Roalson EH, Hall, JC, Riser II JP, Cardinal-McTeague WM, Cochrane TS, Sytsma KJ (2015) A revision of generic boundaries and nomenclature in the North American Cleomoid clade (Cleomaceae). Phytotaxa 205:129-144

Rohela GK, Jogam P, Mir MY, Shabnam AA, Shukla P, Abbagani S, Kamili AN (2020) Indirect regeneration and genetic fidelity analysis of acclimated plantlets through SCoT and ISSR markers in Morus alba L. cv. Chinese white. Biotechnol Rep e00417; https://doi.org/10.1016/j.btre. 2020.e00417

Rohlf FJ (2000) NTSYS 2.1: Numerical Taxonomic and Multivariate Analysis System. Exeter Software, New York

Rohlf FJ, Fisher DR (1968) Tests for hierarchical structure in random data sets. Syst Biol 17(4):407-412

Sadhu S, Jogam P, Thampu RK, Abbagani S, Penna S, Peddaboina V (2020) High efficiency plant regeneration and genetic fidelity of regenerants by SCoT and ISSR markers in chickpea (Cicer arietinum L.). Plant Cell Tiss Organ Cult 141:465-477

Shekhawat JK, Rai MK, Shekhawat NS, Kataria V (2018) Start codon targeted (SCoT) polymorphism for evaluation of genetic diversity of wild population of Maytenus emarginata. Ind Crops Prod 122:202-208

Sirikonda A, Jogam P, Ellendula R, Kudikala H, Mood K, Allini VR (2020) In vitro micropropagation and genetic fidelity assesment in Flemingia macrophylla (Willd.) Merr: an ethnomedicinal plant. Vegetos 33:286-295

Somkuwar SR, Gadpayale JV, Chaturvedi A (2018) Corynandra chelidonii var. pallai (Reddy \& Raju) V.S. Raju, ined. - New addition to the angiospermic flora of Maharashtra, India. IJRBAT, Issue (VI) Spl. Issue 3:38-41

Songsak T, Lockwood GB (2002) Glucosinolates of seven medicinal plants from Thailand. Fitoterapia 73(3):209-216

Sridhar N, Kiran BVS, Sasidhar DT, Kanthal LK (2014) In vitro antimicrobial screening of methanolic extracts of Cleome chelidonii and Cleome gynandra. Bangladesh J Pharmacol 9(2):161-166

Stefunova V, Bezo M, Labajova M, Senkova S (2014) Genetic analysis of three Amaranth species using ISSR markers. Emirates J Food Agric 26(1):35-43

Subhash S, Ragan A (2017) Dormancy and in vitro seed germination of Corynandra chelidonii var. pallae (Cleomaceae), an endemic and ethnomedicinal herb. Int J Pharm Biol Sci 7(2):240-244

Sumitha V, Gurulakshmi M (2015) Antioxidant and free radical scavenging activity of leaf extracts of Cleome chelidonii. Int J Innovation Pharma 2(3):228-236

Sundararaghavan R (1993) Capparaceae. In: Sharma BD \& Balakrishnan NP (ed) Flora of India 2:248-335. Botanical Survey of India, Calcutta

Tamboli AS, Yadav PB, Gothe AA, Yadav SR, Govindwar SP (2018) Molecular phylogeny and genetic diversity of genus Capparis (Capparaceae) based on plastid DNA sequences and ISSR markers. Plant Syst Evol 304(2):205-217

Thakur J, Dwivedi MD, Sourabh P, Uniyal PL, Pandey AK (2016) Genetic homogeneity revealed using SCoT, ISSR and RAPD markers in micropropagated Pittosporum eriocarpum Royle-an endemic and endangered medicinal plant. PloS one 11(7): e0159050

Tripathi N, Chouhan DS, Saini N, Tiwari S (2012) Assessment of genetic variations among highly endangered medicinal plant Bacopa monnieri (L.) from central India using RAPD and ISSR analysis. 3 Biotech 2(4):327-336

Vijayakumar P (1980) Light and Electron Microscopic Studies of the Seed Coat Characteristics of Cleomaceae (Capparaceae) together with their Taxonomic and Phylogenetic Significance. Ph.D. thesis. Kakatiya University, Warangal

Ying W, Ming K, Hongwen H (2007) Subpopulation genetic structure of a plant panmictic population of Castanea sequinii as revealed by microsatellite markers. Front Biol China 2(2):187-195 https://doi.org/10.1007/s11515-007-0027-1

Zhang M, Tucker GC (2008) Cleomaceae. In: Wu CY, Raven PH, Hong DY (ed) Flora of China 7:518-521. Science Press, Beijing 